Portland State University

PDXScholar

4-1-1966

\title{
A series of paintings, drawings, and compositions, oriented toward a fine arts direction in the use of synthetic and mixed media.
}

Judith Frykman

Portland State University

Follow this and additional works at: https://pdxscholar.library.pdx.edu/open_access_etds Let us know how access to this document benefits you.

Recommended Citation

Frykman, Judith, "A series of paintings, drawings, and compositions, oriented toward a fine arts direction in the use of synthetic and mixed media." (1966). Dissertations and Theses. Paper 224.

https://doi.org/10.15760/etd.224

This Thesis is brought to you for free and open access. It has been accepted for inclusion in Dissertations and Theses by an authorized administrator of PDXScholar. Please contact us if we can make this document more accessible: pdxscholar@pdx.edu. 
AN ABSTRACT OF THE THESIS OF

Miss Judith Frykman (Candidate's Name) for the Master of Science in Teaching

Date thesis 1s presented: April 26, 1966

Title: A Series of Paintings, Drawings and Compositions,

Oriented Toward a Fine Arts Direction in the Use of Synthetic

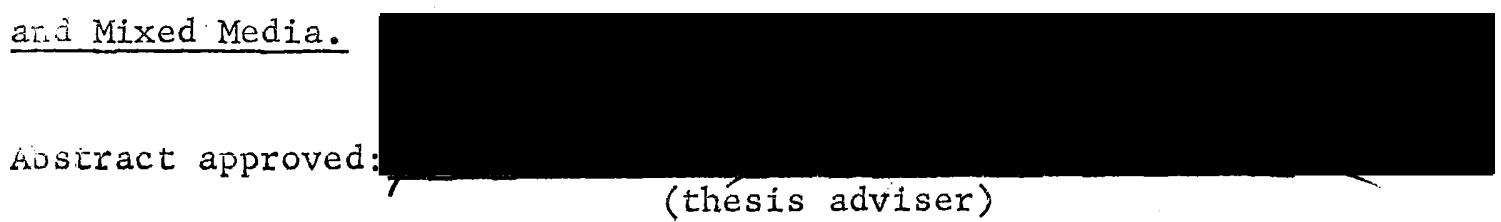

The thesis is in the form of a commentary on the development of ray work from the beginning of this year. The studies have followed a general pattern of closed to open, or linear to painterly. Numerous changes in attitude towards the basic elements of composition, and their use, have taken place. Among those most frequently mentioned are: line, dark and light, intensity and warm-cool color relationships. In connection with these compositional elements, surface texture, subject matter and varius media are discussed. Some consideration is given to conflict between conceptual and media orientations. The effect Oi this conflict in a teaching situation completes the general outline of the thesis. 
APPROVED:

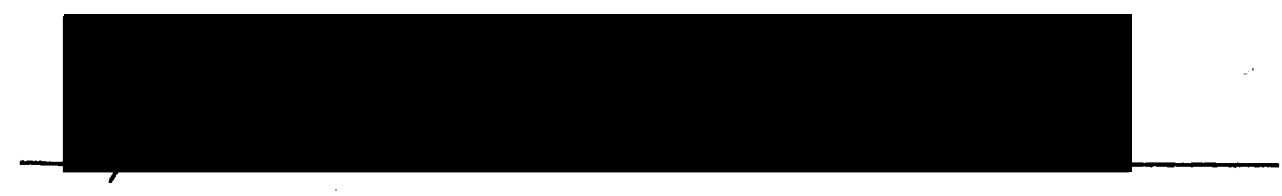

Thesis Adviser

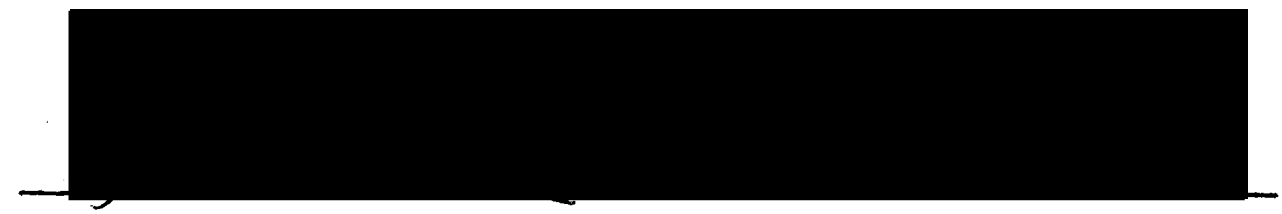

Administrative Officer, Department, Division or School

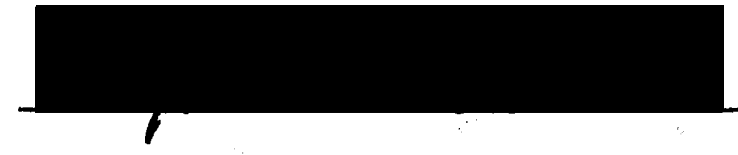

For the Graduate Council

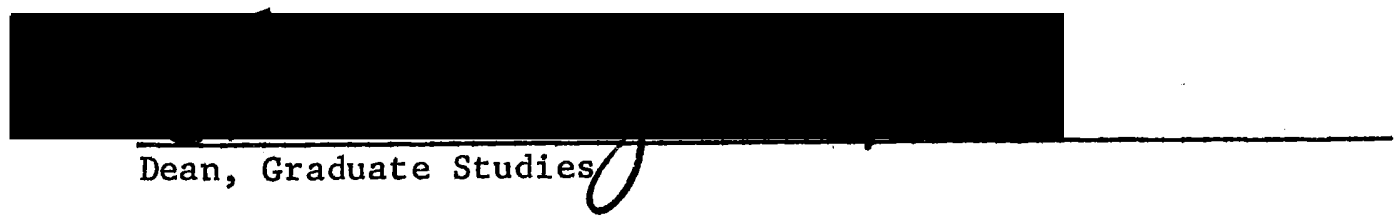

Date thesis is presented: $4-2-66$ 


\author{
A SERIES OF PAINTINGS, DRAWINGS AND \\ COMPOSITIONS, ORIENTED TOWARD A \\ FINE ARTS DIRECTION IN THE USE \\ OF SYNTHETIC AND MIXED MEDIA
}

by

MISS JUDITH FRYKMAN

\author{
A THESIS \\ Presented to the Department of Art \\ and the Graduate Council of Portland State College \\ in partial fulfillment \\ of the requirements for the degree of \\ Master of Science in Teaching \\ Apri1 26, 1966
}


Looktag beck over the work of this yoar. I see that conie Ideat hove come wore clearly into toous. Nany things that oecurred tn comparative teolation tn wy work at the bafining of

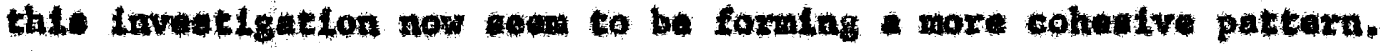
The developmant of ay wexk hat weaned to follow a trond frow Iinear to patntexly, ox eloeed to open. Proviously, I had enoclated the paluterly approach with less aceurany and more upantanlety; however, the comvere cans to be true. Intaking in laxger alemente in ordex to wrive at generallation (which axe condituat mough to read as whole, yet vartuble onough to

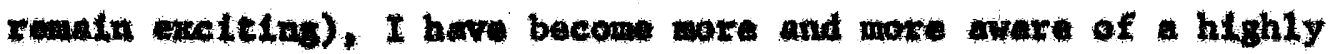
formaliad divelplita. This is not to ray that my work has becond mehanical, but rathre that many and1 dectelons mude hundreds of thes durtug the procese of a patating are taking the place of a fav vell thought out "packegeg" Linked by a Linaar contiguration and surxounded, in meny casos, by wuend epace. When line and odge no langer can be depended upen to bring order out of cheos, the interaction of color bhaper comas to the fore as arimaxy consteration. The apace that the colot oceuples no longer depend on where the shape is draw, but rather, where a color has "put down roote" on a veut plane in ralation to othex color thapes.

Hor a long time, my Lean eonderming colox imotved super-Inpostelog of color over atructured camvas. The 
"compost4lon" in terns of hape vac ectabliahed Aret then the color retnforeed the composition in flat sence. Dark wind 11gtht was the firat considarution; This daxk diatribution, for a lons pertod, we a weattored effort to "balance" the 1tght aroal. The

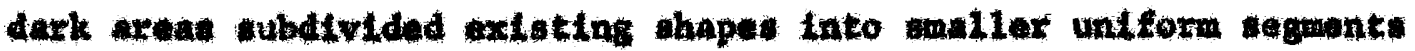
and alternated with widde tons and 1 ghte in overall pattorn. Later, the "whigh" of volue wa ohteted, with largex area of

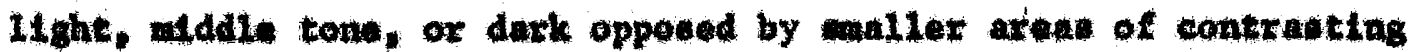
value. Thls ande largar and moxe meanlugful hapes begth to function but bet1 in flat wy, whout any solution of the

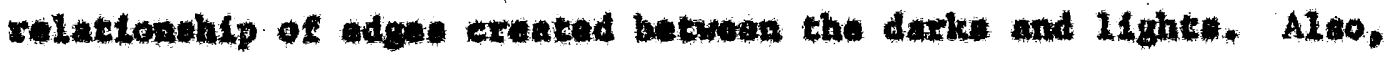

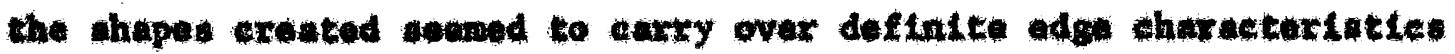
trom the Ldos of 1Lne angles, whteh had pteked up dixactiont

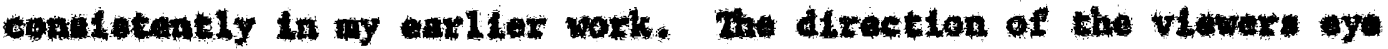
vas belng coatrolled by the edgen of onaped rather than by the

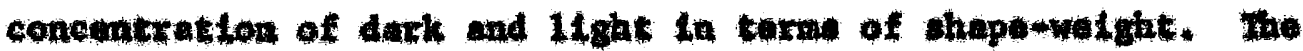

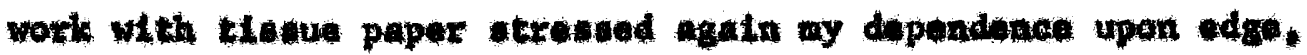

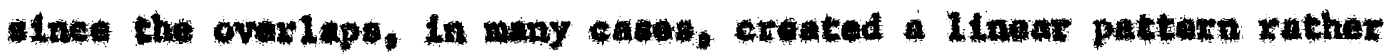
then a value of colox change having any vioual constutancy. Small

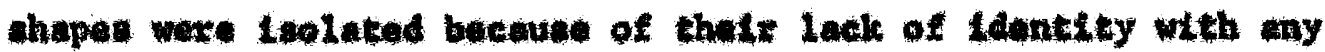
shape in thetr intlax "color-gpace" posttod.

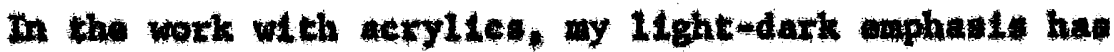
beceme pwogrenetvely lees atchehod to prevloudly contrived ohape. The terno dark aud light have becom doeartptive of a reeding

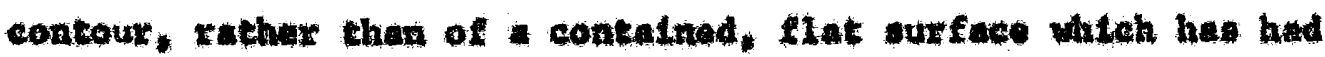


dark and Ilght applled to It deeorativaly. This to not to ony that objoct cannot be ldentLfied an daxk or IIght, but thatr value 1 s mantugtal only in rolation to the value ourxounding thet aree and torm a conalstent epae relattonship with othex areat in a larger sense.

It Is dangerou to diacuss a dhange in atteltude concerning value as leoleted thing. Thio to bucane it has been accon-

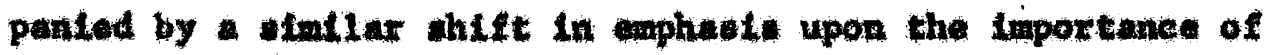
Intenatty wandeol color relattonghip.

In relation to intenalty, wy thluking has becowe wore and mor. directed by the postetion of intenotey in space. sined Intonaty is used so often in ottablishing nex-fax relationehipo at the exponce of the more subtl and rowarding uie of verze and oools, 1t 4 on ingrediont in a patnting which should be uoed for

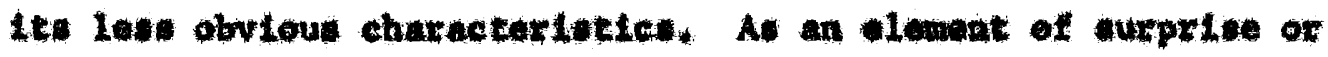
Interent. intendity ean offer ploasins invitation to cacond loak at an othurwtac too mehanteal runderting of an area, Howover,

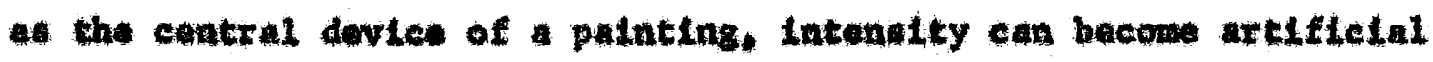
often stving the effect of artifleal lisht on a colorleas wurfece or of tranuttory abmotphorte condition. Intenetty eloni cannot; at once, malce atrong and wuble atatement of volume. By otidinating shrieletng intwasty, the chanees of fragnentation decrease as well as the chanest of over emphasle of one devief. In aselgmants concentrating on Intencity, I found that I was weins Lt to fow 1 lnear patcern moving from whepe to hape and to form 
Iarge upuce conepts the expente of warm-cool vaxtation. Adgh

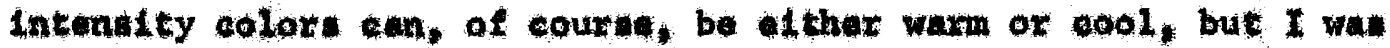

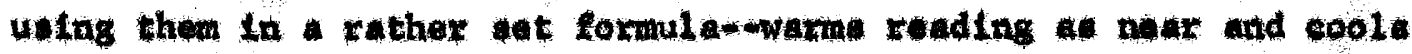
reading as far, In addition, atg intenstty warm, with only

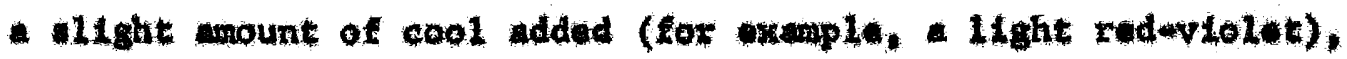
read on the ane plane w a low inkentty cool, with a w1ight amount of warm added (for example, Hight bluemplolet with

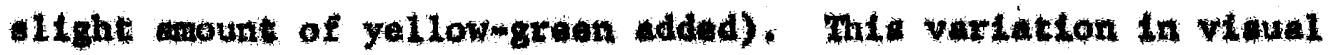
perception gutded my thtnking more and more as I worked wh waxm-cool as an expression of depth.

Wven In the work with tLeve paper, warmecool, as well as Intenslty, played a great part in determinting the mocees of the ploces. It wa traportant an unexpected elewent used in ovorlap. Wor exmaple, an axda trvolving a grean-bxown overlap

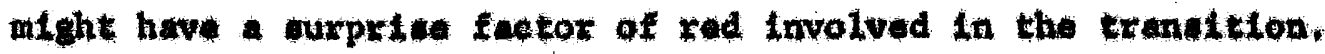
Whthout changlng the value, the viounl rtehness was increaced by the addition of warme to cool axeas and vice-versa. This r lehness cannot occur, however, if thase interest areas are eprinkled throwghout the palating in a haphazard way. They mut be used in connection wth thatr currounding so that the "surpride elenonte" are not all on the ame viaud plane. Somo vil oceur in aore subtle ways, othere in more obviou stuattona.

The most important function of warmucool, however, has come Into focul durtng my work with acrylte and, espectully, 


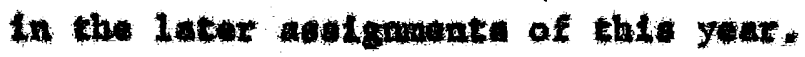

Whan gtven objecte to otate in apace, whout the use of

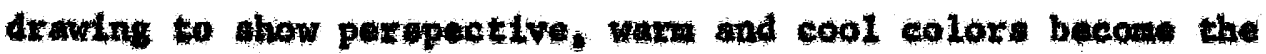

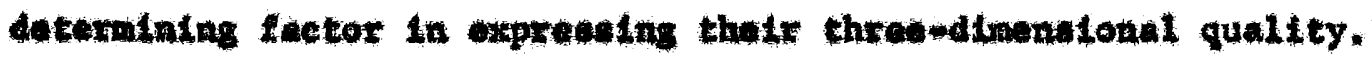
Hot only could it bu uned to how an object recuding from the vievin' aye parallel to the pleture pland, but at an oblique

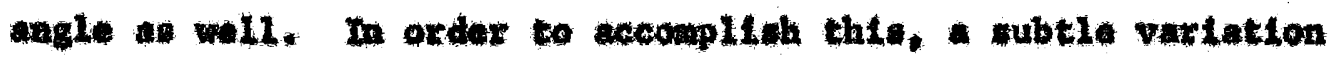

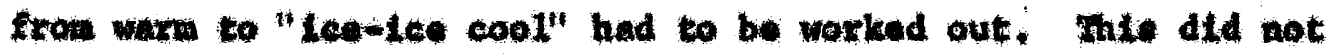
work vil unieas careful condideration was given to the dullest differences in the oddituon of warme and cools to won the wovt noutral color:. A varm grey. in mall quantity surrounded by cools, can jump forwand as wueh as actght red wuxtounded by ruet brewas.

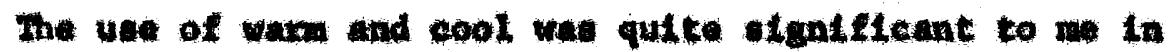

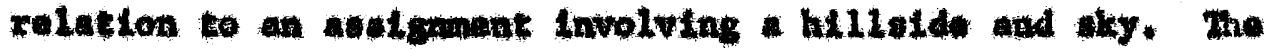
use of varlation of worn and cool colore (frem varm to lea-meol) cauced the hill to auddonly recede into the diatance. Rut, at the two, the importance of wubtle varlation, withth the hL11 form, nede the diffaronge botwen a dengn palnted on a WLII and corles of eolor epote whteh wore, in effect, a hIIL. The ororlope ean form a secondury contour, a value, intenatty, and warm-cool all work together to complate the 111uston. the waxm-cool dopth ean bo onaneed by making the wky oetm to bond forward, (through wermeh), as the hill recedon. Intenatty and

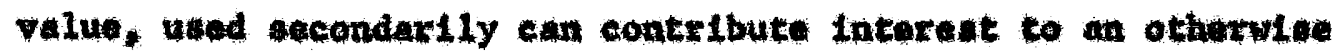


"too well planned" patiting.

the Ldene inwolved th the hill-form putntings becme the bete for addtlonel tudies in landseape, which imvertgated numerous tdeas coneurrently. The flret of these ldent was the over-ridtrit conulderation of wam and cool color: oceupytng a plane In apace. In oxder to folate tha wara-cool problent,

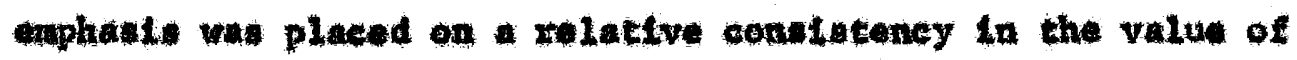
the entire cenvin--that range betng from mLddie tone to 11ght.

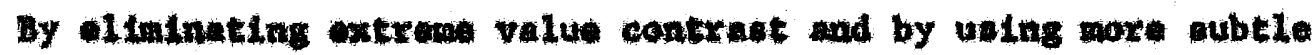
mixture of waw and cool, the palatings fuced we they had not dene betore.

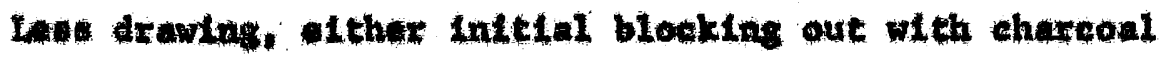
or brubhtstokes suggenting edge, has alto added to the inportance at varm-eool ralatlonehipe. Often, the slightest bint of perppetive octublithes color in opece, contrary to all that has prevtously been butlt up, In the early landocape the carry through of dtrectionel lines waik otili quite evident--forming

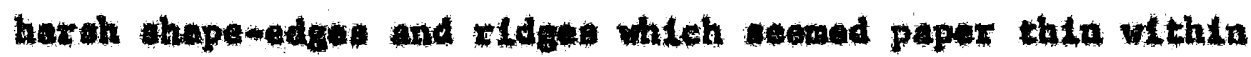
supposediy volumetrie forms. Gadulity this has beth lessened

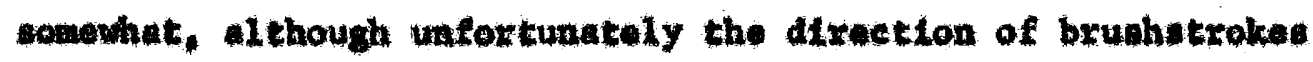

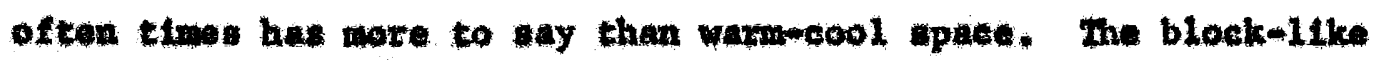
otrokes have been softched, alwo, in an effort to find organle colutiono to Interal ohape varlaclon.

Intentity bas been coftunud constderubly, oven though there ie an oblous nod to it in the entabliohtng of a near-far 
Visual ituation. Although thi could, theoratically, bo elimtnated, at this potat I quatton the validity of an attempt of thio kind. Wth dark-1Lght in wecondary pouttion, it tams that an "Interest area" oupplied by Intendty, perhaps countexbelaneed by elight value change within cortaln areas of a patating, is valfd, Wthout som infeneity and value inter-actlon. the canvar, although integrated, can appar lifalesamuch 14ke - back-drop aratelng more exclting incident. Perhape this feeling is brought about becuuse the varm-cool loment is atil In atate of limbo; it has yot to fully emerge on the cuavas. It could also be mentioned that the lind forms baing uted a subject way be zetponetble for an apperent change in outlook whleh has aot really jalled. If gemetrle oubjec matter were Introduced, ny tendency to become linear in orlentation might reoppeax--Intenatty

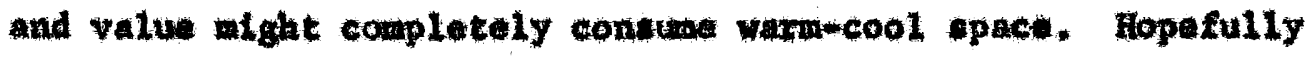
this 111 not occur because of the challengths naturo of my current work, which mat be explored at much gratter depth before I wove toward wore complieated oubject mattex. Dventually the figur. or the clty-ackpe, ean be seen al landscap--tranted with more vibual excltenent due to a mature development of urmmeool inventigatton.

Regarding the epplication of paint, later experimente heve led to desire to explor arface texture. A rteher wurtace may provide wuch of the axclcement which is now delegeted to lerger Intensity and value contrants. Wth wallex bruth otrokes 
and anch under-palnting, the nagular lletag of patnted areas, whleh llown a andl but sparkling surpetad to maxge, may bo the anmer, Thlo contraet, avertholous, would not overahadow the larger warmecool spatial congept.

In this project, there hes been wome conflitet betwedn conceptual and modta ortentation, From the proviou romarke, 1t hould be evidoat that composttional probleas have beon the domtnant fores in the otudy undertaken. When working with now media, such as werylles or vartous mixtures of materials, often the "gtmolel" dictate compaltional constderationa. Ratnters may atn at teaporary affecte in wich the matertal achloves

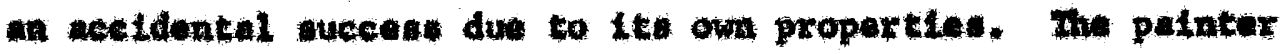
can nelthwer underatend nor ropent these sceldonta, of courus, contideration of the nature of material is an important element in patating but the peintor mus we his watertal rather then

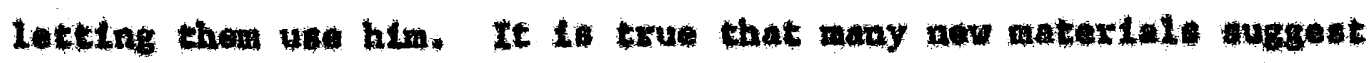
their use to the painter a the work progrueses. He 18 truly in command of the extuation when "eceldente," (todey often contered around texture of tronopureney) are plenusd. If a constent offort to wed to intenelfy conceptual thinkins rathor than material-worehip (governed somettmes by Lttie wore than the laws of nature with the artidt af a vehtele). work of art can be a more weaningful expertence to the vitwex a well as to 1t: erantor. 
Another dangurous delfication can be that of subject. Ho

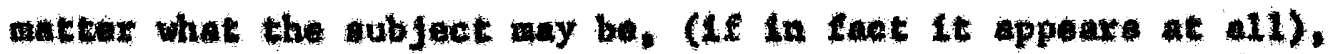
1t muse not be the result of alueprtint whtch could not be

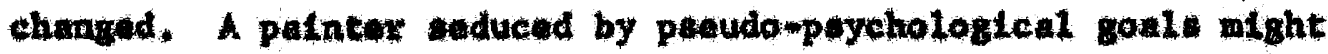
complately Ignore the heart of the painting problem. The placing of "meresge" in prtmiry ponteton whout knowlodge of techatqua

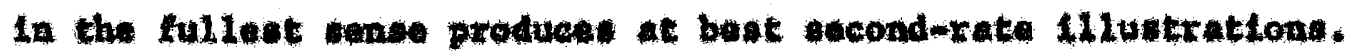
Pexhaps one can over-aetimate the purely visual effect of a

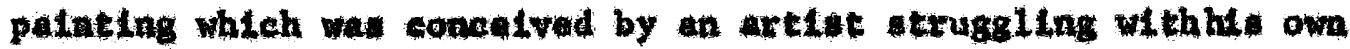
technical problems. Hovever, it nem reasonable thot if the axtiat, or more tmportant, if the pulating wins the battie, valld atoment has norgad.

Tht. Inventigetion has alio produced a change in wy attitude toward the tenching of art. On tinds. In wone cabes.

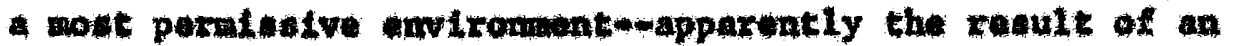
Inadequate gxap of Devey s Incentlve for change. the Ideal of gutdence and directlon has dogoneratad tato chaos. surpriatngly enough. this chaos hav often beon occepted as a abatitute for a crastive euvironnent. In the midet of all thit, wany art oducatore are teching whet they conslder to be the 3 an of art; with little roon for the change or the ohallenge offaxed by new

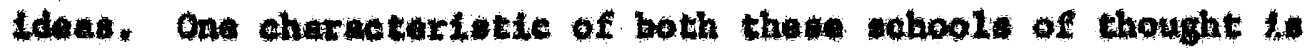
the acceptanse of the Idea that the wore matertale atudent worke whth, the greater his "appreclation" of art. Aguin tho widening of concepte and the relaxation of rigld fommles, coupled 
With effective guidance, wem a logteal antidote to the wadlaor Lentation diserse.

The following photogxaph have bean oelteted to how the development of the ldeas pragented in thi: report. It it hoped that these ctudtes ull 111 utrate without furthor condentary the text af this thest projeat. the otudie appear in the order in which they wore completed. 


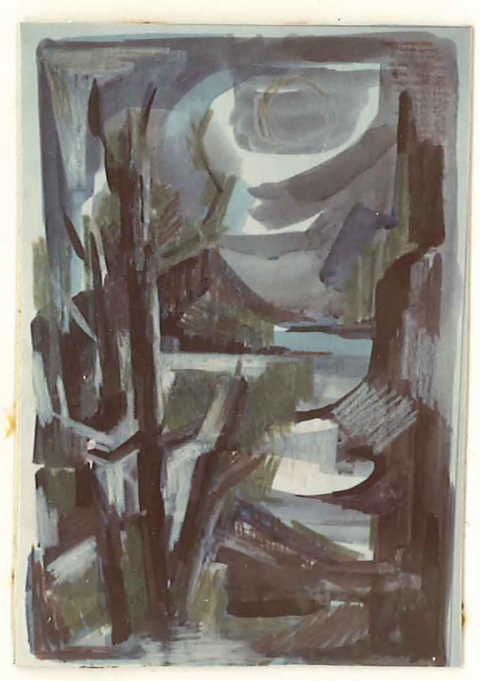




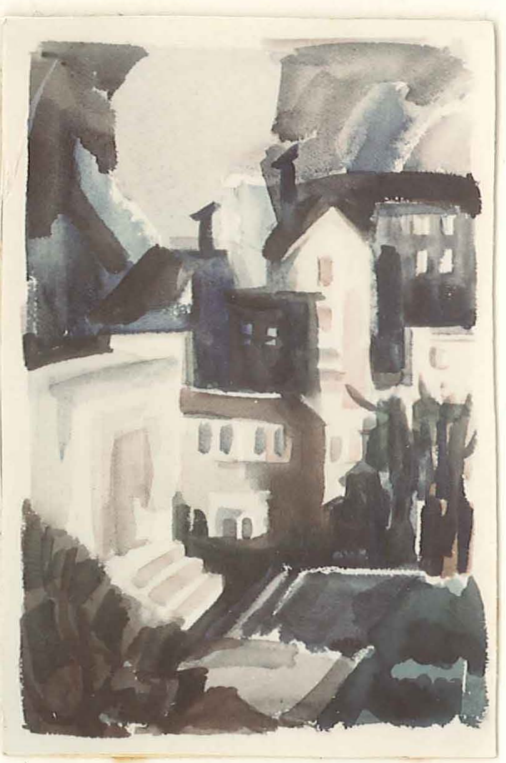




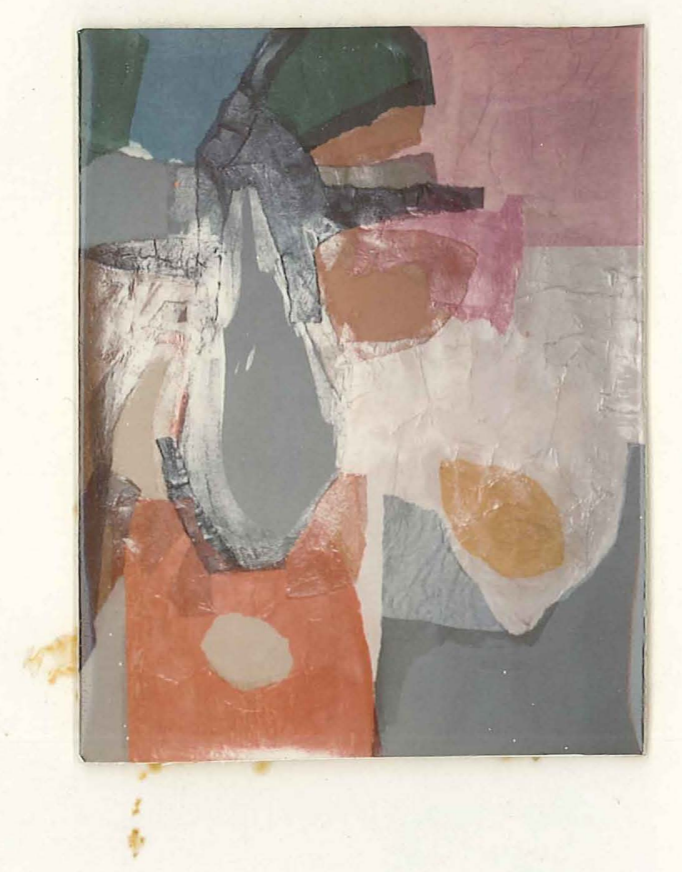




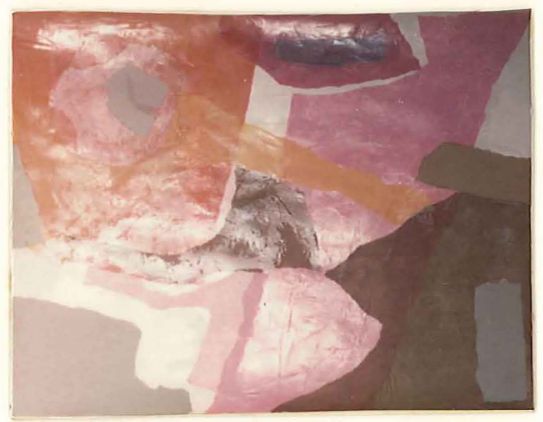




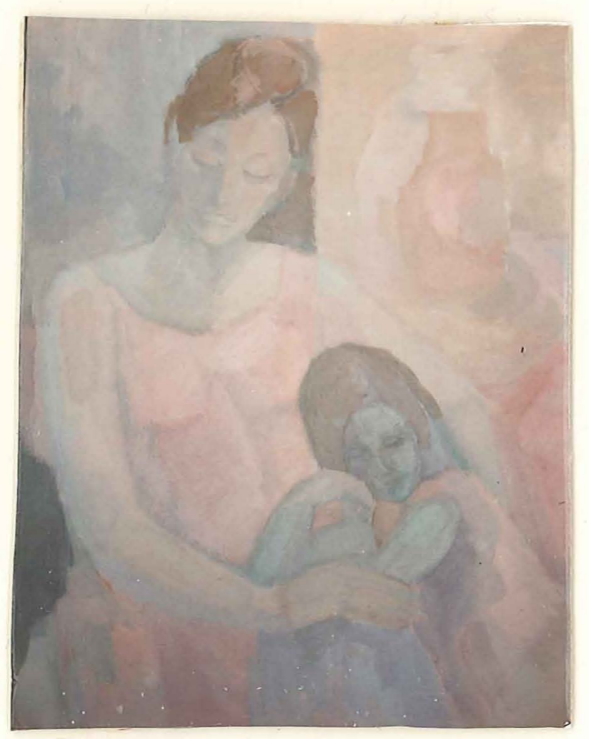

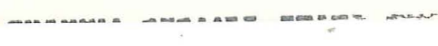




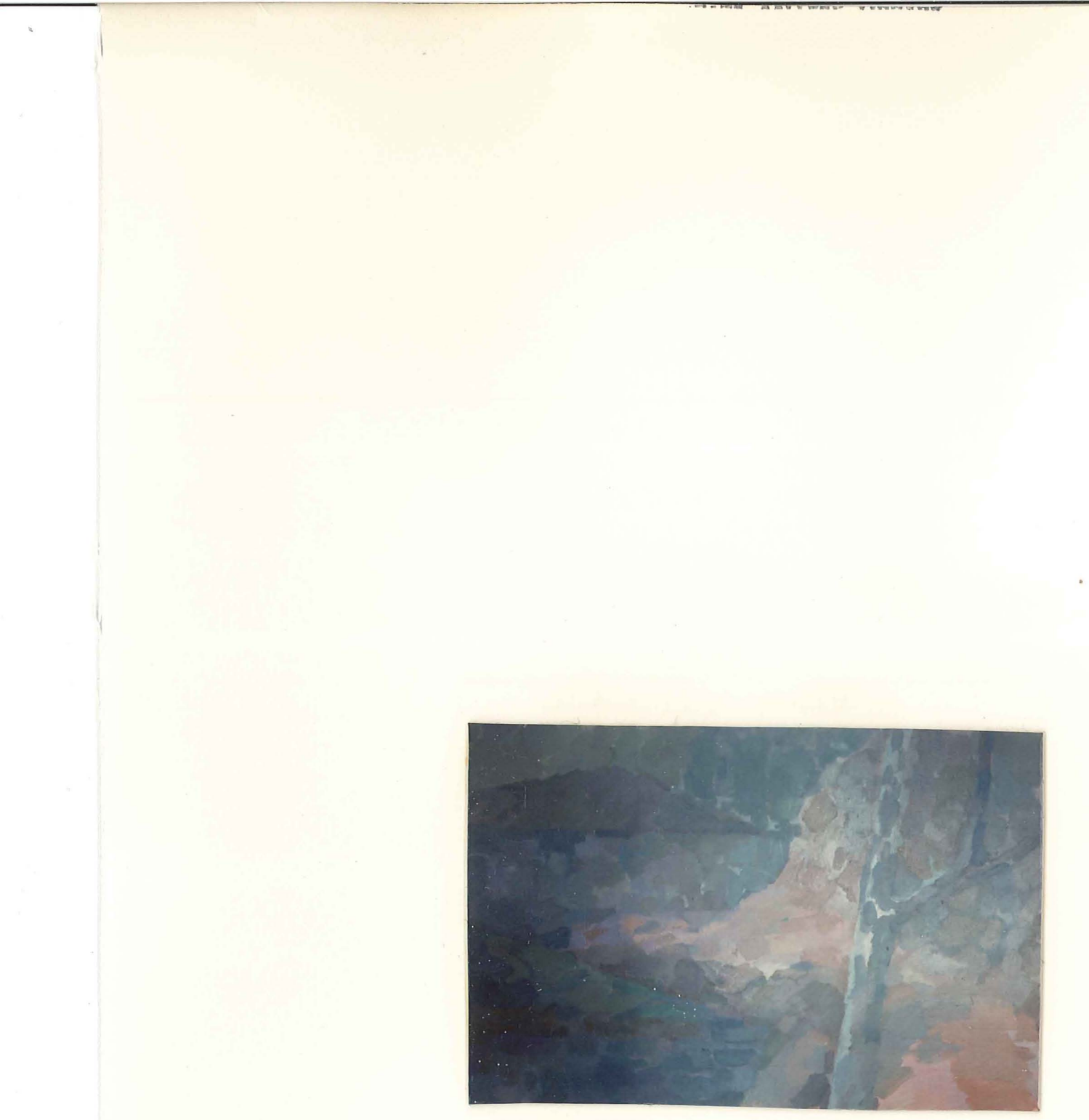

16 


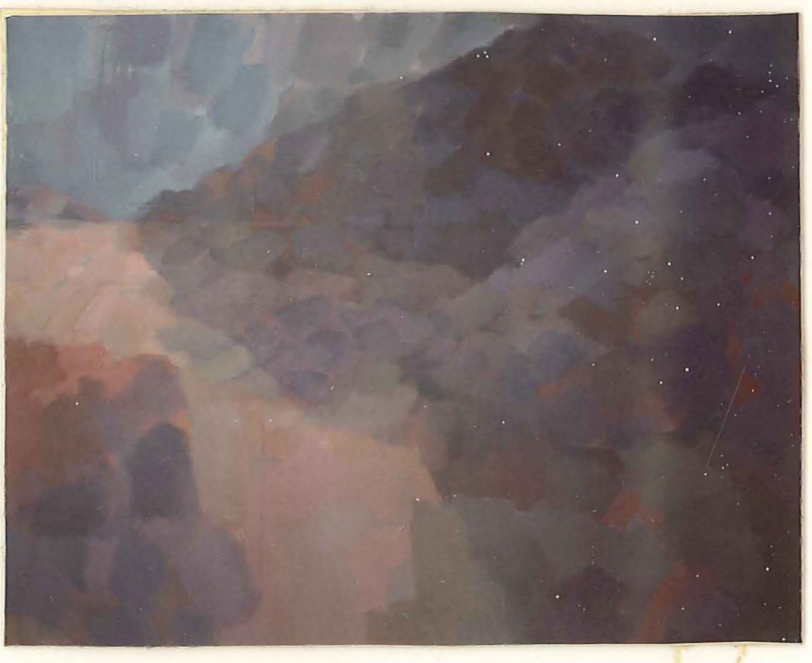




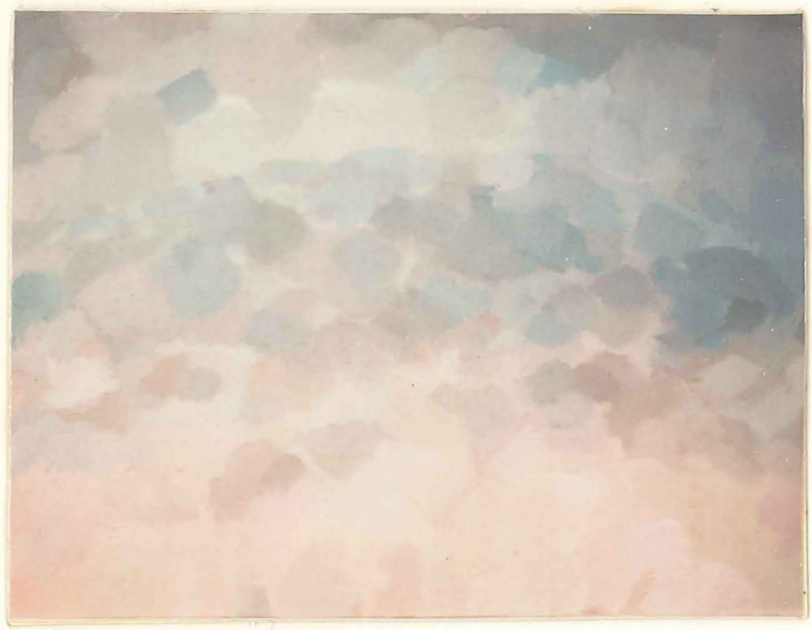

